\title{
Post-Kiobel V. Royal DutCh Petroleum Co.: Is Canada Poised to Become an Alternative Jurisdiction FOR EXTRATERRITORIAL HUMAN RIGHTS LITIGATION?
}

\author{
SEAN E.D. FAIRHURST AND ZOË THOMS*
}

The globalization of business affects the lives of citizens around the globe, both positively and negatively. With multinational corporations transcending national boundaries with their business operations comes the risk of adverse human rights impacts, particularly in regions of the world with high conflict, instability, and low governmental capacity. The risk of human rights violations has led to an increased emphasis on corporate social responsibility measures at industry, national, and international levels. One such protective measure includes statutory grants of jurisdiction to courts to adjudicate claims brought by foreign nationals alleging wrongdoings abroad in the defendant's home jurisdiction. This measure allows foreign plaintiffs who have suffered abuse at the hands of a multinational corporation in their home jurisdiction to seek justice and compensation from that corporate defendant in the jurisdiction where the corporation's assets are located and where the system of law is well-equipped to redress the violations. This article first explores the United States' Alien Tort Statute and the seminal case of Kiobel v. Royal Dutch Petroleum Co. to illustrate the potential scope of extraterritorial human rights litigation in America. Then the article canvasses recent human rights litigation brought by foreign nationals in Canada and concludes with the future of Canadian law in this area.
La mondialisation des affaires a un effet sur la vie des citoyens dans le monde entier, à la fois de manière positive et négative. Comme les multinationales dépassent les frontières nationales de leurs opérations, il y a risque de répercussions néfastes sur les droits de la personne, surtout dans les régions du monde à grands conflits, les régions instables et à faible capacité gouvernementale. Le risque de violations des droits de la personne a amené les entreprises à accentuer les mesures de responsabilité sociale au point de vue industriel, national et international. Une de ces mesures protectrices comprend des concessions d'origine législative aux tribunaux dans le but de statuer sur une réclamation déposée par des étrangers prétextant des actes répréhensibles à l'étranger dans le ressort d'attache du défendeur. Cette mesure permet aux demandeurs étrangers, qui ont fait l'objet d'abus de la part d'une multinationale dans leur propre ressort, de demander justice et indemnisation de la défenderesse dans le ressort où se trouve les actifs de celle-ci et où le système juridique est bien équipé pour réparer les violations. Cet article commence par explorer la loi américaine Alien Tort Statute et l'arrêt faisant autorité Kiobel v. Royal Dutch Petroleum Co. pour illustrer la portée potentielle des litiges extraterritoriaux des droits de la personne aux ÉtatsUnis. L'article passe ensuite en revue les derniers litiges relatifs aux droits de la personne déposés par des étrangers au Canada et conclut en parlant de l'avenir de la loi canadienne en la matière.

\section{TABLE OF CONTENTS}

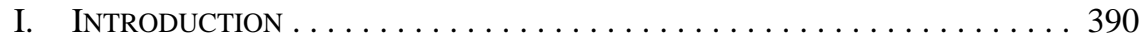

II. ALIEN TORT STATUTE . . . . . . . . . . . . . . . . . . . . . . . . 393

A. History and Evolution of the ALIEN TORT StatuTE . . . . . . 393

B. Kiobel V. Royal DUtCH PETROLEUM CO. . . . . . . . . . . . . . . 397

C. THE UNSETTLED Future OF ALIEN TORT Statute Litigation . . . . . . . . . . . . . . . . . 398

III. RECENT EXTRATERRITORIAL HUMAN RIGHTS LiTIGATION IN CANADA . . . . . . . . . . . . . . . . . . . . . . 399

A. Choc V. Hudbay Minerals InC. — Claim of NegligenCE . . . . 400

Sean E.D. Fairhurst is a partner in the litigation department of McPherson Leslie and Tyerman LLP. Zoë Thoms is a former associate at McPherson Leslie and Tyerman LLP and now practices energy law in Toronto. The authors wish to thank Eugenia Iskra and Stacey Haskins, students-at-law, and Elysa Hogg, summer student, for their research assistance in the preparation of this article. 
B. ASSOCIATION CANADIENNE CONTRE L'IMPUNITÉ (ACCI) C.

ANVIL MINING LTD. - A ClASS ACTION . . . . . . . . . . . . . . 405

C. YAIGUAJE V. CHEVRON CORP. -

RECOGNITION OF FOREIGN JUdGMENTS . . . . . . . . . . . . . . . 411

IV. DeVElopments ANd Future Changes in CANAdian LAW . . . . . . . . . 414

A. BILL C-323 AN ACT TO AMEND THE

FEDERAL COURTS ACT (INTERNATIONAL PROMOTION

AND PROTECTION OF HUMAN RIGHTS) _ . . . . . . . . . . . 414

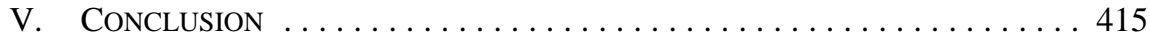

\section{INTRODUCTION}

As business has expanded across national boundaries, so too has its power to affect the lives of citizens around the globe. These effects may be positive, bringing immense economic benefits where before there was little growth. These effects may also be negative, including the prospect of adverse human rights impacts. This reality has led to an increased emphasis on corporate social responsibility (CSR) measures within industry and at national ${ }^{1}$ and international levels. ${ }^{2}$ One goal of CSR initiatives, amongst others, is to enact measures and processes to prevent violations of human rights occurring in the course of business operations. Unfortunately, despite these measures, issues still do arise. For example, the international extractive sector often requires companies to operate in regions with high conflict, instability, or low state institutional capacity. Companies with operations in these regions are exposed to the added risk of becoming involved in events, either directly or indirectly, which may result in human rights violations against the local population.

If these victims of human rights violations wish to seek compensation, they necessarily require an adjudicative centre for the hearing of claims. Victims may face difficulties accessing a court able and willing to hear their claims. Presently, there is no dedicated tribunal at the international level to assess or adjudicate such claims. Plaintiffs are left to make use of domestic law and procedure either in their home jurisdiction, in the home jurisdiction of the corporate defendant, or in some other jurisdiction that can be petitioned to hear the claim. For the last 30 years, the United States federal courts frequently heard claims by non-US citizens relating to human rights violations occurring around the world pursuant to a provision known as the Alien Tort Statute. ${ }^{3}$ The ATS extends the jurisdiction of the US federal courts to foreign plaintiffs seeking compensation for torts committed in 1 In 2009, the federal government of Canada announced a voluntary corporate social responsibility Development Canada, Building the Canadian Advantage: A Corporate Social Responsibility (CSR) Strategy for the Canadian International Extractive Sector (March 2009), online: Government of Canada $<$ www.international.gc.ca/trade-agreements-accords-commerciaux/topics-domaines/other-autre/csr-stratrse.aspx>

2 In 2005, the United Nations established a mandate for a Special Representative of the Secretary-General on the issue of human rights and transnational corporations and other business enterprises. In 2011, the Special Representative, John Ruggie, issued a report containing guiding principles pursuant to that mandate: John Ruggie, Guiding Principles on Business and Human Rights: Implementing the United Nations "Protect, Respect and Remedy" Framework, UNHRC, 17th sess, Annex, Agenda Item 3, UN Doc A/HRC/17/31 (2011) at 6.

328 USC $\$ 1350(2006)[$ ATS $]$. 
violation of the "law of nations" or international customary law. ${ }^{4}$ A recent decision of the US Supreme Court, however, has created uncertainty as to the availability of the ATS going forward for these types of claims.

In 1980, the $A T S$, which up until then was a seldom-used provision enacted by the First Congress in 1789, was revived by non-US citizens to avail themselves of the US judicial system in seeking redress from perpetrators of human rights violations. ${ }^{5}$ Since then, jurisprudence interpreting and applying the ATS has evolved to capture the actions of state actors, private individuals, and corporations around the world. The decision in Kiobel $v$. Royal Dutch Petroleum Co., ${ }^{6}$ however, significantly curtailed the availability of the ATS on the basis of the presumption against extraterritoriality. The Court held that in order for a claim to fall within the ATS it must "touch and concern the territory of the United States, [and] ... do so with sufficient force to displace the presumption against extraterritorial[ity].””

The Court's decision in Kiobel narrowed the availability of the ATS, and by extension the availability of the US courts, for the purposes of adjudicating claims seeking redress for human rights violations suffered elsewhere. With the procedural advantage of the ATS compromised, plaintiffs may now be searching for new jurisdictions willing and able to hear these types of claims - jurisdictions such as Canada.

Canada currently does not have comparable legislation to the ATS. A private member's bill before the House of Commons, however, proposes to amend the Federal Courts Act ${ }^{8}$ to expressly permit persons who are not Canadian citizens to initiate tort claims based on violations of international law or treaties to which Canada is a party if the alleged acts occur outside Canada. ${ }^{9}$ The bill has not advanced beyond first reading. Comments from the sponsoring MP, Mr. Peter Julian (Burnaby-New Westminster, NDP) at the reintroduction of the bill indicate that the bill is intended to mirror the ATS and is targeted at the conduct of Canadian corporations abroad, specifically Canadian mining companies:

The bill calls for extending the authority of the Federal Court system to protect foreign citizens against a broad range of human rights violations committed by Canadian and non-Canadian corporations and persons operating outside Canada. It would allow lawsuits in Canada for a host of universal human rights violations, such as genocide and torture, as well as activities that significantly destroy the environment or violate key international labour rights.

Canada's judicial system protects Canadians from abusive conduct by corporations or individuals and should no longer permit some Canadian corporations to violate human rights abroad. These continue to be committed abroad with impunity by some bad apples, some Canadian mining companies and other

See Jonathan Horlick et al, "American and Canadian Civil Actions Alleging Human Rights Violations Abroad by Oil and Gas Companies” (2008) 45:3 Alta L Rev 653 at 654 .

Ibid at 655-58.

133 S Ct 1659 (2013) [Kiobel (USSC)].

Ibid at 1669.

RSC 1985 , c F-7.

Bill C-323, An Act to amend the Federal Courts Act (international promotion and protection of human rights), 1st Sess, 41st Parl, 2011 (first reading 5 October 2011) [Bill C-323]. 
companies. This has an impact and, as a result, we need to ensure that we have a court system that responds to the needs of these foreign nationals. ${ }^{10}$

Even without Canadian ATS-type legislation, former Supreme Court Justice Ian Binnie has recently called for Canadian courts to respond to the claims of foreign plaintiffs seeking redress for human rights violations occurring elsewhere, calling for boldness from Canadian judges to address the issues that have traditionally been barriers to foreign plaintiffs:

It is not realistic to expect the creation of some sort of international tribunal to adjudicate such claims given the volume of complaints around the world particularly in the extractive industries; nor, if the present lack of progress is any indication, is it likely that the international community will agree on a convention defining the appropriate circumstances for domestic courts to take jurisdiction. For the foreseeable future domestic judges will either have to wash their hands of the whole problem or rethink some of the doctrines that stand in the way of granting relief. ${ }^{11}$

Recent decisions from the Superior Court in Ontario in Choc v. Hudbay Minerals Inc., ${ }^{12}$ and Quebec in Association canadienne contre l'impunité (ACCI) c. Anvil Mining Ltd. ${ }^{13}$ suggest that some Canadian judges may have heard Justice Binnie's call to judge boldly and provide foreign plaintiffs alleging human rights violations with the opportunity to be heard in Canadian courts. While these cases only decided preliminary motions, they have already raised interesting questions relating to the legal concepts of jurisdiction and corporate personality, two of the doctrines identified by Justice Binnie as requiring a "rethink." The outcome of those cases that proceed to a full hearing will undoubtedly have significant consequences for the future frequency of extraterritorial human rights litigation in Canadian courts, but so too will those cases that are simply able to avoid dismissal at a preliminary stage of the proceeding. It is the ability to continue prosecution of the claim that is valuable and communicates to prospective claimants that a receptive jurisdiction has been identified.

This article will provide an overview of the modern evolution of the ATS, including the recent decision of the US Supreme Court in Kiobel which calls into question the utility of the ATS for extraterritorial human rights litigation. This article will then consider political and legal developments in Canada relating to extraterritorial human rights litigation, including recent decisions from Ontario and Quebec which consider legal concepts critical to future litigation in this area, as well as a proposal for the inclusion of an ATS-type amendment to the Federal Courts Act. Before'” (The Coxford Lecture, delivered at the University of Western Ontario, 16 February 2012), (2013) 26:1 Can JL \& Jur 5 at 18.

2013 ONSC 1414, 116 OR (3d) 674 [Choc].

2011 QCCS 1966, [2011] JQ No 4382 (QL) [Anvil (Qc CS)], rev’d 2012 QCCA 117, [2012] RLQ 153 [Anvil (Qc CA)]. 


\section{Alien Tort Statute}

\section{A. History AND Evolution OF THE Alien ToRT Statute}

The $A T S$ was enacted by the First Congress of the United States in 1789 . The text of the ATS is brief:

The district courts shall have original jurisdiction of any civil action by an alien for a tort only, committed in violation of the law of nations or a treaty of the United States. ${ }^{14}$

The ATS was rarely invoked in the 200 years following its enactment. Prior to the 1980 decision in Filartiga $v$. Pena-Irala ${ }^{15}$ the $A T S$ was raised in fewer than two dozen proceedings before the US federal courts with jurisdiction upheld in only two cases. ${ }^{16}$ In present times, courts and commentators have struggled to understand the original meaning of the ATS and to apply that meaning in the modern-day context. The "law of nations" as referenced in the ATS has evolved considerably since the eighteenth century, and the succinct text of the ATS provides little interpretive guidance. Anthony J. Bellia Jr. and Bradford R. Clark in their article undertook an extensive analysis of the historical legal and political context in which the ATS was enacted to understand the original meaning and purpose of the ATS:

In 1789, the most natural way to read the ATS, given its full legal and historical context, was as a grant of jurisdiction to federal district courts to hear common law tort claims by aliens against United States citizens for intentional injuries to person or property. Such harms violated the law of nations and, if not redressed by the perpetrator's nation, gave the victim's nation just cause for war. In light of these background principles, the ATS is best understood as a self-executing, fail-safe measure that enabled the United States to avoid responsibility for law of nations violations by permitting aliens to sue US citizens for intentional torts in federal courts. 17

As will be discussed further below, Bellia and Clark's interpretation of the original meaning and application of the ATS differs from the interpretation articulated by the US circuit court in Filartiga, ${ }^{18}$ and still further from the interpretation determined by the US Supreme Court in Sosa v. Alvarez-Machain. ${ }^{19}$

The first modern consideration of the ATS was the 1980 case of Filartiga. This case involved a claim brought by two Paraguayan nationals against a state actor (Inspector

$14 \quad$ ATS, supra note 3.

$15 \quad 630 \mathrm{~F}(2 \mathrm{~d}) 876$ (2d Cir 1980) [Filartiga].

The two cases where jurisdiction was upheld were described in the decision of Filartiga, ibid at $887 \mathrm{n}$ 21:

[The ATS] afforded the basis for jurisdiction over a child custody suit between aliens in Adra $v$. Clift, 195 F.Supp. 857 (D.Md.1961), with a falsified passport supplying the requisite international law violation. In Bolchos v. Darrell, 3 Fed.Cas. 810 (D.S.C.1795), the Alien Tort Statute provided an alternative basis of jurisdiction over a suit to determine title to slaves on board an enemy vessel taken on the high seas.

See also Anthony J Bellia Jr \& Bradford R Clark, "The Alien Tort Statute and the Law of Nations" (2011) 78:2 U Chicago L Rev 445 at 458; Theresa (Maxi) Adamski, "The Alien Tort Claims Act and Corporate Liability: A Threat to the United States’ International Relations” (2011) 34:5 Fordham Int'l LJ 1502 at 1512.

Bellia \& Clark, ibid at 454.

Supra note 15.

542 US 692 (2004) [Sosa]. 
General of Police in Paraguay) in relation to the kidnapping, torture, and murder of a family member in Paraguay as retaliation against the plaintiffs' political activities and beliefs. The plaintiffs cited the $A T S$ both as a cause of action and as granting the federal court jurisdiction to hear their complaint.

The district court at first instance dismissed the complaint on jurisdictional grounds, concluding that the federal court did not have jurisdiction over the subject matter of the claim. In specific regard to the ATS, the district court held that the court was constrained by precedent to construe narrowly the "law of nations" as referenced in the ATS as "excluding that law which governs a state's treatment of its own citizens." 20

The decision was appealed to the Second Circuit where the Court held that while the ATS did not grant rights to foreign parties, it did operate to open the federal courts for adjudication of the rights already recognized by international law. According to Bellia and Clark, the Court interpreted the ATS expansively to allow "aliens to sue other aliens for violations of international law that occurred outside of the United States." 21 The Court held that three elements of the case triggered ATS jurisdiction: (1) a tort action, (2) brought by an alien (only), (3) for violations of the law of nations. ${ }^{22}$ The Court held that the relevant international law was not limited to that of 1789 when the ATS was enacted. ${ }^{23}$ The Court determined that international law must be interpreted as it has evolved and exists among the nations of the world today with reference to the works of jurists writing on the topic, the usage and practice of nations, and judicial decisions recognizing and enforcing that law. ${ }^{24}$ The Court went on to conclude that "there are few, if any, issues in international law today on which opinion seems to be so united as the limitations on a state's power to torture persons held in its custody."25

The next key development in ATS interpretation was the case of Kadic v. Karadzic. ${ }^{26}$ Kadic concerned a claim brought by victims of the Bosnian war against a non-state actor, the leader of insurgent Bosnian Serb forces, for human rights violations, torture, and summary execution, as well as war crimes and genocide committed during the war. In Kadic, the Court considered whether a private individual could be sued in his private capacity for these violations of the law of nations.

The district court dismissed the claim for lack of subject-matter jurisdiction concluding that acts committed by non-state actors did not violate the law of nations. ${ }^{27}$ On appeal to the Second Circuit, the Court disagreed with the lower court's approach that the law of nations, in the modern era, "confines its reach to state action"; rather, certain forms of conduct violated the law of nations "whether undertaken by those acting under the auspices of a state or as private individuals." 28 The Court cited the examples of piracy, slavery, and war crimes.

Filartiga, supra note 15 at 880.

Bellia \& Clark, supra note 16 at 459.

Filartiga, supra note 15 at 887.

Ibid at 881.

Ibid at 880 .

Ibid at 881.

70 F (3d) 232 (2d Cir 1995) [Kadic].

Ibid at 237.

Ibid at 239. 
With respect to torture and summary execution, the Court held that while state-sanctioned torture and summary execution are proscribed by international law, private individuals may only be held liable for these violations when such acts are perpetrated in the course of genocide or war crimes. ${ }^{29}$

In 1997, an ATS case was brought against a corporate defendant in Doe v. Unocal Corp. ${ }^{30}$ The plaintiffs in Unocal were Burmese villagers who alleged that Unocal had engaged the Burma military to provide assistance during the construction of a gas pipeline in Burma, and that while so engaged, the military committed human rights violations including, forced labour, murder, rape, and torture. The plaintiffs argued Unocal had aided and abetted the Burmese military in these actions.

Given that this was one of the first times that a corporation had been named as a defendant in an ATS proceeding, ${ }^{31}$ there is surprisingly little consideration in the decision at either the first instance or on appeal as to whether and in what circumstances a corporation can be held to have violated the law of nations. The district court dismissed the plaintiffs' claims on the basis that Unocal had not directly engaged in state action, nor had Unocal controlled the Burmese military at the time the human rights violations had occurred. The appellate court took as its starting point that a "threshold question in any $[A T S]$ case against a private party, such as [a corporation], is whether the alleged tort requires the private party to engage in state action" in order to be held liable. ${ }^{32}$ Citing Kadic, the Court noted that crimes like rape, torture, and summary execution, which by themselves require state action for an individual to be held liable, do not require state action when committed in furtherance of other crimes like slave trading, genocide, or war crimes. ${ }^{33}$ The Court held that "forced labor is a modern variant of slavery" and ruled that, "like traditional variants of slave trading," state action by the private actor is not required to give rise to liability under the $A T S .{ }^{34}$ The Court overturned the dismissal of the portion of the claim against Unocal relating to aiding and abetting in procuring forced labour.

Following Unocal, a number of other ATS actions were brought against corporations, including Shell, ${ }^{35}$ Chevron, ${ }^{36}$ Barclay National Bank, ${ }^{37}$ ExxonMobil, ${ }^{38}$ Occidental, ${ }^{39}$ Rio Tinto, ${ }^{40}$ Coca-Cola, ${ }^{41}$ Royal Dutch Petroleum, ${ }^{42}$ and the Canadian energy company Talisman Energy. ${ }^{43}$ Like in Unocal, the plaintiffs in these cases did not allege that corporations had directly carried out human rights violations. Rather, the complaints against the corporations

Ibid at 243 .

395 F (3d) 932 (9th Cir 2002) [Unocal].

Adamski, supra note 16 at 1506, n 11.

Ibid at 945 [emphasis in original].

Ibid at $945-46$.

Ibid at 946.

Kiobel v Royal Dutch Petroleum Co, 621 F (3d) 111 (2d Cir 2010) [Kiobel (2d Cir)].

Bowoto v Chevron Texaco Corp, 312 F Supp (2d) 1229 (ND Cal 2004).

Khulumani v Barclay National Bank Ltd, 504 F (3d) 254 (2d Cir 2007).

Doe VIII v Exxon Mobil Corp, 654 F (3d) 11 (DC Cir 2011).

Galvis Mujica v Occidental Petroleum Corp, 564 F (3d) 1190 (9th Cir 2009); Carijano v Occidental Petroleum Corp, 548 F Supp (2d) 823 (CD Cal 2008).

Sarei v Rio Tinto, PLC, 671 F (3d) 736 (9th Cir 2011).

Bigio v The Cola-Cola Company, 239 F (3d) 440 (2d Cir 2000); Sinaltrainal v Coca-Cola Company, 578 F (3d) 1252 (11th Cir 2009).

Wiwa v Royal Dutch Petroleum Company, 226 F (3d) 88 (2d Cir 2000).

Presbyterian Church of Sudan v Talisman Energy Inc, 582 F (3d) 244 (2d Cir 2009). 
was aiding and abetting and conspiring with the state (often military) in the state's violations. ${ }^{44}$ In almost all of these $A T S$ cases against corporations, "the question of whether a corporation could be sued appears to have been assumed, with neither defendants raising it as a concern,” nor courts addressing it in their decisions. ${ }^{45}$

In 2004, in the decision of Sosa, the US Supreme Court for the first time considered the modern invocation of the ATS, reviewing the history and context of its enactment. Sosa concerned the kidnapping of the plaintiff, a Mexican citizen, to return him to the US to stand trial for the torture and killing of a US federal agent in Mexico. The plaintiff brought an action under the ATS against the US federal agents and Mexican citizens involved in his kidnapping, alleging that his abduction violated his civil rights. ${ }^{46}$

The Court affirmed that the ATS was a jurisdictional statute creating no new causes of action, and that the ATS was "enacted on the understanding that the common law would provide a cause of action for the modest number of international law violations with a potential for personal liability at the time” of enactment. ${ }^{47}$ The Court concluded that the historical record suggested that at the time the ATS was enacted, the torts that would have been contemplated by the First Congress corresponded to Blackstone's three primary criminal offences against the law of nations: violation of safe conduct, infringement of the rights of ambassadors, and piracy. ${ }^{48}$ When applying the $A T S$ in the context of the present-day law of nations, the Court held that such norms must be "of international character accepted by the civilized world and defined with a specificity comparable to the features of the 18thcentury paradigms we have recognized." 49

The Court applied its analysis of the ATS to the plaintiff's claim and concluded that such a claim based on "a single illegal detention of less than a day, followed by the transfer of custody to lawful authorities and a prompt arraignment, violates no norm of customary international law so well defined as to support the creation of a federal remedy." 50 The Court did not directly address the application of the ATS to corporate defendants. However, in a footnote, the Court commented that a related consideration to the issue of whether a cause of action ought to be subject to jurisdiction under the ATS is "whether international law

$44 \quad$ Horlick et al, supra note 4 at 658.

45 Odette Murray, David Kinley \& Chip Pitts, "Exaggerated Rumours of the Death of an Alien Tort? Corporations, Human Rights and the Remarkable Case of Kiobel” (2011) 12:1 Melb J Int'l L 57 at 59. Sosa, supra note 19 at 698.

Ibid at 724.

Ibid.

Ibid at 725. However, Bellia \& Clark, supra note 16 at 542-43 argue that the Court's analysis in Sosa was overly narrow:

The ATS was not adopted, however, to grant federal courts jurisdiction merely to hear a narrow class of torts committed by individuals acting on behalf of a government and analogous to the three international crimes that Blackstone singled out. Rather, the statute was designed to redress ordinary torts committed by private US citizens against aliens. The reason was simple: any intentional common law tort committed with force by a US citizen against the person or property of an alien constituted a violation of the law of nations and imposed an obligation on the United States to redress the injury or become responsible to the alien's nation. Thus, it was the basic party alignment - rather than some specific characteristic of the underlying intentional tort — that triggered jurisdiction under the ATS [footnotes omitted]. 
extends the scope of liability for a violation of a given norm to the perpetrator being sued, if the defendant is a private actor such as a corporation or individual."

\section{B. Kiobel V. Royal Dutch Petroleum Co.}

In Kiobel, the US Supreme Court again had an opportunity to consider the ATS. Kiobel concerned a class action brought by Nigerian citizens against Royal Dutch Petroleum Company and other Dutch, British, and Nigerian corporations (collectively Royal Dutch) engaged in the exploration and production of oil in the Ogoni region of Nigeria. The plaintiffs claimed that Royal Dutch had aided and abetted the Nigerian government in committing human rights violations.

Some Ogoni people had organized a group to protest the environmental effects of oil exploration in the region. The plaintiffs alleged that in 1993, Royal Dutch "responded by enlisting the aid of the Nigerian government to suppress" these protests. ${ }^{52}$ The plaintiffs alleged that the Nigerian military forces then shot and killed Ogonis, attacked Ogoni villages, beat, raped, and arrested residents, and destroyed and looted property, all with the assistance of Royal Dutch. ${ }^{53}$ Specifically, the plaintiffs alleged that Royal Dutch provided transportation to Nigerian forces, allowed corporate property to be used as a staging ground for attacks, and provided food and payment to soldiers involved in the attacks. ${ }^{54}$

On appeal, the Second Circuit dismissed the plaintiffs' claim on the basis that corporations could not be held liable under the ATS because there is no norm of customary international law that recognizes the liability of corporations for violations of international law. ${ }^{55}$ The Court stated that this issue had been "lurking" for some time in ATS jurisprudence and that ATS cases involving corporations had been decided in the past without squarely addressing the issue of corporate liability. ${ }^{56}$ The Court specifically referenced the footnote in Sosa as setting out the issue to be considered. ${ }^{57}$ The Court cautioned that the fact that corporations are "liable as juridical persons under domestic law does not mean that they are liable under international law (and therefore, under the ATS)."58 The Court held that the instances where the law of nations imposed individual liability for a limited number of crimes (as established in Kadic) could not be extended to corporate parties. The Court discussed at length, that "customary international law has steadfastly rejected the notion of corporate liability for international crimes, and no international tribunal has ever held a corporation liable for a violation of the law of nations."59 Prior to the ruling in Kiobel, a number of decisions allowing for ATS claims to proceed against corporations had been issued from the same

Ibid at 732, n 20, where the Court also referenced two actions discussing liability of private actors: Compare Tel-Oren v. Libyan Arab Republic, 726 F. 2d 774, 791-795 (CADC 1984) (Edwards, J., concurring) (insufficient consensus in 1984 that torture by private actors violates international law), with Kadic v. Karadžić, 70 F. 3d 232, 239-241 (CA2 1995) (sufficient consensus in 1995 that genocide by private actors violates international law).

Kiobel (2d Cir), supra note 35 at 123.

Ibid.

Ibid.

Ibid at 149 .

Ibid at 124 .

Ibid at 120, n 18.

Ibid at 118 .

Ibid at 120 . 
circuit. The Second Circuit's decision created uncertainty as to the status of corporate defendants in ATS litigation and the case was appealed to the US Supreme Court.

After oral argument at the US Supreme Court on the issues raised at the appellate level, the Court directed the parties to file supplemental briefs addressing an additional question: "Whether and under what circumstances the [ATS] allows courts to recognize a cause of action for violations of the law of nations occurring within the territory of a sovereign other than the United States." 60 The Court was concerned with the principle of statutory interpretation known as the presumption against extraterritorial application, which provides that when a statute gives no indication of an extraterritorial application, it has none. ${ }^{61}$

In contemplating the issue of the extraterritorial application of the ATS, the Court, repeating $\operatorname{Sos} a$, noted "the need for judicial caution in considering which claims could be brought under the ATS, in light of foreign policy concerns." 62 After reviewing the text of the $A T S$ and historical context in which it was enacted, the Court held that there was nothing to suggest that the First Congress intended the causes of action recognized under the ATS to have extraterritorial reach. ${ }^{63}$ Further, the Court concluded that there was "no indication that the ATS was passed to make the United States a uniquely hospitable forum for the enforcement of international norms." ${ }^{64}$ Applying its interpretation to the plaintiffs' claim, the Court held that all relevant conduct took place outside the US and that the claim did not touch and concern the territory of the US with sufficient force to displace the presumption against extraterritorial application. ${ }^{65}$ With that, the Court held that the claim was barred.

The Supreme Court did not comment on the appellate court's conclusion regarding corporate liability for violations of the law of nations; however, the Court did make a passing reference to the presence of a multinational corporation in a jurisdiction as being insufficient to displace the presumption against extraterritorial application. The Court noted that "[i]f Congress were to determine otherwise, a statute more specific than the ATS would be required."66

\section{The Unsettled Future of Alien Tort Statute Litigation}

The future of ATS human rights litigation in the US is unsettled. There does not appear to be any legislative initiative to amend the ATS as deemed necessary by the Supreme Court in Kiobel to displace the presumption against extraterritorial application. Going forward without such a legislative amendment, the courts will have to develop factors that would be sufficient to establish that a claim "touched and concerned" the US with "sufficient force" to displace the presumption against extraterritoriality. ${ }^{67}$ As it stands, without recourse to the $A T S$, foreign

Kiobel (USSC), supra note 6 at 1663.

Ibid at 1664 .

Ibid.

Ibid at $1665-68$.

Ibid at 1668 .

Ibid at 1669.

Ibid.

In one recent $A T S$ case, a district court held that the attack on a US Embassy in Nairobi sufficiently

"touched and concerned" the US: Mwani v Bin Laden, 417 F (3d) 1 (DC Cir 2005). 
plaintiffs seeking recovery from foreign defendants will have to establish jurisdiction in the normal course of proceedings.

\section{RECENT EXTRATERRITORIAL HUMAN RIGHTS LITIGATION IN CANADA}

While the availability of the ATS was an advantage to foreign plaintiffs proceeding in US courts, other characteristics of the US legal system also made it a favourable forum for litigation. These characteristics include the availability of contingency fee and pro bono arrangements, that losing parties are not always responsible for an opponent's legal costs, the availability of class action proceedings, expansive discovery proceedings, and the chance of high damage awards, including punitive damages ${ }^{68}$ If it is in fact the case that, following the Kiobel decision, the US is no longer as open to hearing extraterritorial human rights litigation, plaintiffs may look to other jurisdictions to have their claims heard. In particular, they may seek jurisdictions which share some of the advantageous characteristics of the US legal system described above.

Despite the absence of ATS-type legislation, Canada's legal system shares a number of characteristics with the US legal system which may influence plaintiffs when selecting a jurisdiction. For example, Canada's legal system also allows for the use of contingency fees, pro bono arrangements, and class proceedings. As well, in the Canadian legal system, losing parties are not always responsible for an opponent's costs. Canada does not have as expansive discovery rights as in the US, nor are damage awards by Canadian courts as large. In this last respect, Canada may well be a preferable jurisdiction for corporate parties exposed to this type of litigation.

A plaintiff seeking compensation in Canadian courts for human rights violations which occur outside of Canada has a number of options when choosing to advance his or her claim. A plaintiff may obtain a judgment from the courts of his or her home jurisdiction and seek to have the judgment recognized in Canada's courts for enforcement against the defendant's assets located in the jurisdiction. Alternatively, a plaintiff may commence a claim in a Canadian court. The rules of civil procedure of the various Canadian provinces and territories govern the procedure for bringing a claim. A threshold issue for any litigation is that in order for a claim to be heard in Canadian courts, it must fall within the court's inherent jurisdiction. Even then, the court may decline to exercise jurisdiction in favour of a more appropriate forum.

In his article, “Globalization, International Human Rights, and Civil Procedure,” Trevor C.W. Farrow explores the modern convergence of three traditionally separate topics: globalization, international human rights, and civil procedure. ${ }^{69}$ In the context of globalization and human rights, Farrow argues that civil procedure has become a "gatekeeper" and plays a powerful role in determining whether a party may have access to rights and remedies: a default judgment and delivered a verdict of $\$ 4.5$ billion in damages against Karadzic.

69 Trevor CW Farrow, “Globalization, International Human Rights, and Civil Procedure” (2003) 41:3 Alta L Rev 671. 
Civil procedure is, in the end, about power. It is about power — albeit often retrospectively — to regulate individual and corporate behavior. It is about power to manage efficiently and resolve expectations, transactions, and disputes. And, ultimately, it is about power to access meaningful substantive rights and remedies in a fair and fulsome way. In the context of globalization and international human rights, far from merely being a tool of parochial domestic process, civil procedure has become a gatekeeper in this era of modern commerce and social intercourse: a gatekeeper to the access of meaningful justice — through the protection and/or the recognition of basic rights and liberties - for parties involved in civil matters with global contacts. ${ }^{70}$

In recent years, a small number of foreign plaintiffs have advanced claims in Canadian courts against Canadian corporations involved in the international extractive sector. ${ }^{71}$ Defendants have made use of the rules of civil procedure to challenge the plaintiffs very early in the proceedings arguing that an action should be struck or stayed on the basis that the court lacks jurisdiction or that the claim fails to disclose a reasonable cause of action.

Former Supreme Court Justice Ian Binnie has called on the Canadian courts and legal community to react to the issues raised by extraterritorial human rights litigation and notes that the law has a lot of catch-up work to do:

In the case of Canada, the overseas economic activity of our mining companies is enormous. Attempts at federal legislation have been unsuccessful. In the absence of statutory authority the courts have not yet addressed issues related to globalization and human rights with the sort of boldness and creativity we associate with great judges like Ivan Rand. ${ }^{72}$

Justice Binnie identifies two particular areas which require judicial boldness as they relate to globalization and human rights litigation: the jurisdiction of necessity, and an update to the doctrine of the "corporate veil."73 These concepts were at the centre of the recent decisions in Choc, Anvil, and Yaiguaje v. Chevron Corp. ${ }^{74}$ and rulings in these cases may be a sign that some judges are heeding Justice Binnie's call for boldness.

\section{A. ChoC V. Hudbay Minerals Inc. - Claim of Negligence}

\section{THE CORPORATE VEIL}

One of the issues that foreign plaintiffs face in bringing a claim against a corporate defendant is that the corporation operating in the plaintiffs' home jurisdiction is often only one part of a complex multinational corporate structure. Canadian law has long recognized that a corporation is a legal entity distinct from its shareholders, and a parent corporation is also legally distinct from a subsidiary. As Justice Binnie notes:

Ibid at 673 [footnotes omitted].

See Recherches Internationals Québec v Cambior inc, [1998] QJ No 2554 (QL) (CS) [Recherches]; Piedra v Copper Mesa Mining Corp, 2010 ONSC 2421, [2010] OJ No 2239 (QL), aff'd 2011 ONCA 191, 332 DLR (4th) 118; Choc, supra note 12; Anvil (Qc CS), supra note 13.

Binnie, supra note 11 at 19.

Ibid at 20-21.

2013 ONSC 2527, 361 DLR (4th) 489 (Sup Ct J) [Yaiguage (Sup Ct J)], rev’d 2013 ONCA 758, 118 OR (3d) 1 [Yaiguaje (CA)]. 
This concept, deeply rooted in corporate law, is used regularly to deny liability of the head office, with its deep pockets, for acts of its subsidiaries in the far flung regions of the world where, it is alleged, the wrongful acts occurred. In a corporate pyramid the profits flow up the chain to the top (or are taken at whatever corporate level seems most advantageous) but legal liability remains stuck at the bottom where there may be liability but shallow pockets. ${ }^{75}$

Under Canadian law, this “corporate veil” may be pierced in very specific circumstances: (1) when a corporation has been completely dominated, controlled, and used as a shield for fraudulent or improper conduct; ${ }^{76}(2)$ where a principal-agency relationship exists; ${ }^{77}$ or (3) where a statute permits. ${ }^{78}$

Plaintiffs must be precise in pleading their claims in order to pierce the distinct corporate identities between a parent corporation and its foreign subsidiaries. In the recent case of Choc, the plaintiffs' pleadings survived a preliminary motion to strike brought by the defendants in respect of claims relating to a parent company's liability for the actions of its subsidiary.

In 2011, three actions were commenced in the Ontario Superior Court by indigenous Mayan Q'eqchi’ from El Estor, Guatemala against a Canadian mining company, Hudbay Minerals, and its wholly-controlled foreign subsidiaries, in respect of human rights violations allegedly committed by private security personnel in Guatemala such as murder, violent assault, and rape. ${ }^{79}$ The plaintiffs alleged that these violations were committed during the forced relocation of the Q'eqchi' from the vicinity of a proposed open-pit nickel mining operation known as the Fenix mining project. ${ }^{80}$ The Q'eqchi' had previously claimed legal rights to the contested lands and had reclaimed and occupied a small part of the lands which comprise the Fenix property. ${ }^{81}$

The defendant Hudbay is a Canadian mining company headquartered in Toronto. Hudbay held a majority interest in the subsidiary Compañía Guatemalteca De Níquel (CGN), which in turn owned the Fenix project. ${ }^{82}$ The defendant HMI Nickel Inc. (HMI) is a former Canadian mining company which had amalgamated with Hudbay. HMI had previously owned and operated the Fenix project. ${ }^{83}$

Binnie, supra note 11 at 20-21.

Elbow River Marketing Limited Partnership v Canada Clean Fuels Inc, 2012 ABCA 328, 539 AR 68 at para 16 citing Transamerica Life Insurance Co of Canada v Canada Life Assurance Co (1996), 28 OR (3d) 423 (Gen Div) at para 433-34.

77 Thomas G Heintzman \& Brandon Kain, “Through the Looking Glass: Recent Developments in Piercing the Corporate Veil” (2013) 28:3 BFLR 525 at 539, n 76:

The agency basis for imposing liability is distinct from piercing the corporate veil, since the former assumes that the corporation and controlling mind are distinct, whereas the latter ignores the legal persona of the corporation: Dumbrell v. Regional Group of Companies Inc. (2007), 85 OR (3d) 616 (CA) at para. 80. Nonetheless, the two concepts are frequently conflated by the courts: see Globex Foreign Exchange Corp. v. Launt (2011), 335 DLR (4th) 257 (NSCA) at paras. 21-22. Ibid at 539.

Choc, supra note 12 at para 4.

Ibid.

Ibid at paras 11-13.

Ibid at para 8.

Ibid at para 9 . 
The defendants initially intended to bring a motion to challenge the jurisdiction of the Ontario court to hear the claims arguing that the more appropriate forum was Guatemala. They subsequently elected not to proceed with the jurisdiction motion, and instead brought a second motion to argue that the plaintiffs' claims should be struck on the basis that they failed to disclose a reasonable cause of action. ${ }^{84}$ The test applied by the Court on a motion to strike pleadings is whether, "assuming the facts set forth in the statement of claim can be proven, is it plain and obvious that no reasonable cause of action is disclosed." ${ }^{85}$

The Court identified two possible causes of action in negligence as articulated in the statement of claim: (1) Hudbay's vicarious liability for the tortious conduct of its subsidiary CGN and CGN's employees or agents (such liability would require a piercing of the corporate veil); and (2) Hudbay's direct liability for its actions leading to the human rights violations, including "wrongdoing in its on-the-ground management of the Fenix project, and in particular, its negligent management of the Fenix security personnel." ${ }^{\prime 86}$

Canadian law recognizes the legal distinction between a corporation and its shareholders often referred to as the "corporate veil." As discussed above, Canadian courts have recognized three circumstances in which the legal principle can be set aside and the corporate veil can be pierced. The first two were relevant to this proceeding: (1) where the corporation is completely controlled and being used as a shield for fraudulent or improper conduct; and (2) where the corporation has acted as the authorized agent of its controllers, corporate or human. ${ }^{87}$

Regarding the first exception, the Court held that the plaintiffs' claim in this regard failed as they had not plead the second element, noting that "[t]he fact that Hudbay allegedly engaged in wrongdoing through its subsidiary is not enough to pierce the corporate veil. The plaintiffs would have to allege that Hudbay had used CGN 'as a shield for fraudulent or improper conduct', that the very use of CGN was to avoid liability for wrongful conduct that it carried out through CGN." ${ }^{88}$

The Court did find however that the plaintiffs had properly pleaded the second exception in one of the actions in pleading that CGN was an agent of Hudbay in CGN's decision to retain the private security forces. The Court concluded that "the claim based on piercing the corporate veil ... should be allowed to proceed to trial.".89

id at para 1. The defendants brought two further motions: (a) in the event that the first motion to strike was successful, the defendants sought to have the remaining action stayed or dismissed on the ground that the Ontario Superior Court did not have jurisdiction and (b) the defendants moved to strike one of the actions on the basis that the limitation period had expired. The Court denied both of these motions. Ibid at para 40 .

Ibid at paras 25, 31 .

Ibid at para 47 citing Shoppers Drug Mart Inc v 6470360 Canada Inc, 2012 ONSC 5167, [2012] OJ No $4320(\mathrm{QL})$ at paras 72-73.

Choc, ibid at para 48; Rules of Civil Procedure, RRO 1990, Reg 194, r 21.01(1)(b).

Choc, ibid at para 49. 


\section{DUTY OF CARE}

In order to show direct negligence, the plaintiffs did not claim that Hudbay was responsible for the torts committed by the private security personnel. Rather, the plaintiffs claimed Hudbay was directly negligent in failing to prevent the harms committed by the private security personnel. ${ }^{90}$ The Court recognized that this claim of negligence was based on a novel duty of care and, accordingly, applied the test to establish a novel duty of care as prescribed by the Supreme Court of Canada (the Anns/Cooper test). ${ }^{91}$

The Anns/Cooper test to establish a novel duty of care has three parts, as summarized by the Court in Choc:

(1) that the harm complained of is a reasonably foreseeable consequence of the alleged breach;

(2) that there is sufficient proximity between the parties that it would not be unjust or unfair to impose a duty of care on the defendants; and,

(3) that there exist no policy reasons to negative or otherwise restrict that duty. ${ }^{92}$

If foreseeability and proximity are established, a prima facie duty of care is found to exist, subject to the consideration of public policy in the third branch of the Anns/Cooper test.

Regarding foreseeability, the Court noted that the plaintiffs had pleaded that Hudbay had knowledge of the use of violence by security personnel during forced evictions, that such violence had been used in previous forced evictions that Hudbay had requested at the Fenix site, and "that the security personnel were unlicensed, inadequately trained and in possession of unlicensed and illegal firearms." 93 The Court held that the facts as pleaded, "if proven at trial, could establish that the harm complained of was the reasonably foreseeable consequence of the defendants' conduct." 94

The second branch of the Anns/Cooper test is whether there is a proximate relationship between the plaintiffs and defendants. The Court referenced the plaintiffs' pleadings which stated that representatives of Hudbay had made public statements which indicated that Hudbay had turned its mind to the issue of how to deal with the ongoing land conflict between it and the Q'eqchi' and that representatives of Hudbay had made public statements that Hudbay had adopted the Voluntary Principles on Security and Human Rights, a set of standards applicable to the use of private security forces at resource extractive projects. ${ }^{95}$ The plaintiffs had also pleaded that Hudbay's executives and employees were directly in charge

Ibid at para 52.

See Anns v Merton London Borough Council (1977), [1978] AC 728 [Anns]; Cooper v Hobart, 2001 SCC 79, [2001] 3 SCR 537 [Cooper].

92 Choc, supra note 12 at para 57, citing Odhavji Estate v Woodhouse, 2003 SCC 69, [2003] 3 SCR 263 at para 52.

Choc, ibid at para 63.

Ibid at para 65 .

Ibid at para 67; online: Voluntary Principles on Security and Human Rights < www.voluntaryprinciples. org $>$. 
of on-the-ground operations of the Fenix project, including both community relations and security. ${ }^{96}$

The Court held that the public statements by Hudbay concerning its relationship with local communities and its commitment to respecting human rights would have led to certain expectations on the part of the plaintiffs. The Court concluded that, based on the pleadings, it would not be unjust or unfair to impose a duty of care on the defendants and held that a "prima facie duty of care may be found to exist for the purposes of the motion."97

The Court then turned to the final branch of the Anns/Cooper test: whether there are any policy reasons to negate or otherwise restrict the prima facie duty of care. The defendants argued that recognizing such a duty risks exposing any Canadian company with a foreign subsidiary to a myriad of meritless claims and would likely impinge upon the fundamental principle of separate corporate personality. ${ }^{98}$ In a previous hearing, the Court had granted Amnesty International intervener status to provide submissions with respect to issues of law and the concept of direct parent liability. ${ }^{99}$ Amnesty also made submissions with respect to the policy reasons for recognizing such a duty of care, namely that, "in order to preserve Canada's reputation, Canadian society has a strong interest in ensuring that Canadian corporations respect human rights, wherever they may operate and whatever ownership and business structure they may put in place to advance their operations in foreign countries." 100

The Court noted that, given the competing policy considerations advanced by the plaintiffs, defendants, and intervener in recognizing a duty of care in the present circumstances, this alone would prevent the Court from finding it plain and obvious that this branch of the Anns/Cooper test would fail. In addition, the Court noted authorities which cautioned against dismissing a claim based on policy reasons at the motion stage before there is a complete record before the Court. ${ }^{101}$ The Court went on to dismiss the defendants' applications.

\section{CONCLUSION}

The Court did not make any findings of fact or determinations of the merits of the plaintiffs' claims. The defendants will be permitted to raise their arguments against the recognition of the novel duty of care again at trial. The practical implications of this ruling, however, is that the defendants must now proceed with complex and costly litigation. This case, should it proceed to trial, has the potential to set a precedent with far-reaching impacts for the international extractive sector in particular, and potentially all Canadian corporations operating overseas.

Choc, ibid at para 69.

Ibid at para 70 .

Ibid at para 72.

Ibid at para 37. See United Canadian Malt Ltd v Outboard Marine Corp of Canada Ltd (2000), 48 OR

(3d) 352 (Sup Ct J).

Choc, ibid at para 39.

Ibid at para 74 citing Haskett v Equifax Canada Inc (2003), 63 OR (3d) 577 at para 52. 


\title{
B. ASSOCIATION CANADIENNE CONTRE L'IMPUNITÉ (ACCI) C. AnVil Mining LtD. - A Class ACtion
}

\section{JURISDICTION}

Jurisdiction is perhaps the most important area of civil procedure triggered in the intersection between globalization, international human rights, and civil procedure. ${ }^{102}$ Foreign plaintiffs in Canadian courts may face early challenges from defendants in respect of the jurisdiction of the court to hear the claim. In assessing whether a court has jurisdiction to hear a claim, the court considers whether there is a "real and substantial connection" between the dispute and the chosen forum. ${ }^{103}$ Even where a court finds that it has jurisdiction to hear a claim, a court may decline to hear the claim on the basis that there is some other more convenient forum. ${ }^{104}$ As Farrow points out, the issue of jurisdiction raises the theme of power:

\begin{abstract}
The question of whether a court is willing to grant or deny jurisdiction over a given cause of action or litigation becomes, in the end, a question of power. Because different justice will be dispensed in different jurisdictions, the decision to afford or deny jurisdiction is a threshold decision that ultimately may mean the difference between meaningful justice gained and meaningful justice denied. ${ }^{105}$
\end{abstract}

In Anvil, the corporate defendants opposed an application for authorization to institute a class action and sought a declaration that the Quebec Superior Court lacked jurisdiction to hear the claims brought by the foreign plaintiffs or, in the alternative, that the proposed class members' home jurisdiction was preferable to Quebec.

The plaintiff, the Association canadienne contre l'impunité (ACCI), was the creation of five non-governmental organizations which came together to incorporate in Quebec ${ }^{106}$ with the mission to represent residents of the town of Kilwa, in the province of Katanga in the Democratic Republic of Congo (DRC or Congo) in respect of a proposed class action. The class action related to Anvil Mining Ltd.'s (Anvil Mining) involvement in human rights violations which occurred during a military operation in Kilwa in October $2004 .{ }^{107}$ The

Club Resorts Ltd v Van Breda, 2012 SCC 17, [2012] 1 SCR 572 at para 69 [Van Breda].

Ibid at paras 101-103. Recherches, supra note 71, was a class action brought in the Quebec Superior Court by foreign plaintiffs against Cambior, a Canadian mining company which owned an interest in a gold mine in Guyana through a Guyanese subsidiary. The claim concerned the collapse of a dam storing effluent containing cyanide and heavy metals which contaminated two nearby rivers. Local investigations determined that the breach of the dam was a result of faulty construction. Cambior contested the proposed class action on the basis that the Quebec Superior Court lacked jurisdiction or, in the alternative, should decline jurisdiction on the basis that Guyana was the more convenient forum. The Court concluded that both Quebec and Guyana had jurisdiction to try the issues and moved on to consider the appropriate forum. The plaintiffs claimed that the victims would be denied justice if the case was heard in Guyana, and in support relied on the expert evidence of a Quebec law professor who had conducted a survey of the legal system and concluded that the inefficiencies were so great so as to undermine due process. Cambior submitted conflicting expert evidence. The Court preferred Cambior's evidence on the point and held that this case was one of the exceptional instances where the court ought to decline to exercise its jurisdiction.

Farrow, supra note 69 at 691 [footnotes omitted].

ACCI was incorporated pursuant to Part III, Division III of the Companies Act, RSQ, c C-38. Anvil (Qc CA), supra note 13 at paras 21-26. 
designated member, Adèle Mwayuma, lost two sons and all of her property during the military operation. ${ }^{108}$

Anvil Mining was a Canadian mining company founded in January 2004 in the Northwest Territories. ${ }^{109}$ Its head office was in Perth, Australia and its main activity was the operation of a copper mine near Kilwa in the DRC. ${ }^{110}$ The lack of transportation infrastructure in the DRC required that Anvil Mining transport ore from its mine through port installations in Kilwa, across Lake Mweru, and into neighbouring Zambia where it was sent on to processing facilities in South Africa and Namibia. ${ }^{111}$

On 13 October 2004, a small group of armed insurgents from Zambia entered the town of Kilwa and proclaimed the independence of Katanga from DRC. Informed of the situation, the Congolese government dispatched the army to take back control of Kilwa within 48 hours. The army lacked the necessary transportation to get to Kilwa in time to execute its orders. Anvil Mining provided trucks and drivers to transport the troops to Kilwa. As well, Anvil Mining transported troops on its plane to Kilwa after evacuating Anvil Mining personnel to a nearby centre. Anvil Mining's position was that it did not have a choice in the matter and that its assistance was requisitioned by the government. ${ }^{112}$ The plaintiff, meanwhile, alleged that Anvil had provided the logistical assistance on its own initiative and in its own interest. ${ }^{113}$

Reports of what transpired when the Congolese troops arrived in Kilwa differ. The Supreme Military Court of the DRC concluded that fighting between the army and insurgents resulted in several deaths on both sides and a number of houses burned. ${ }^{114}$ The United Nations Organization Mission in the Democratic Republic of Congo conducted an investigation of the October 2004 operation and concluded that the armed forces summarily executed approximately 100 civilians and plundered the property of the residents of Kilwa. ${ }^{115}$

The proposed class action sought damages on the grounds that the actions of the Congolese army against the population of Kilwa, with Anvil Mining's assistance and knowledge, constituted crimes against humanity and that by acting as an accomplice to these crimes, Anvil Mining assumed its responsibility pursuant to Congolese domestic law. ${ }^{116}$ Anvil Mining opposed the certification of the class action arguing that Quebec lacked the jurisdiction to hear the claim. Under article 3148(2) of the Civil Code of Québec, jurisdiction may be established when the defendant is a legal person, is not domiciled in Quebec but has an establishment in Quebec, and the dispute relates to the defendants’ activities in Quebec. ${ }^{117}$

Association Canadienne Contre L'Impunité c Anvil Mining Limited (Requête Pour Autorisation D’Exercer Un Recours Collectif et Pour Être Désignée Représentane, 8 November 2010) at para 2.33 [Anvil, Class Action Pleading].

In March 2010, Minmetals Resources Ltd. (now MMG Limited) acquired Anvil Mining Ltd. in a friendly takeover bid: “Company History," online: MMG <www.mmg.com/en/About-Us/companyoverview/company-history.aspx>.

Ibid.

Anvil, Class Action Pleading, supra note 108 at para 2.44. Anvil (Qc CS), supra note 13 at para 2.

Anvil, Class Action Pleading, supra note 108 at para 2.81.

Anvil (Qc CS), supra note 13 at para 2.

Anvil, Class Action Pleading, supra note 108 at para 2.73 .

Ibid at para 2.165 .

Art 3148(2) CCQ. 
Anvil Mining argued that the test to establish jurisdiction in Quebec in the present case was not met because at the time of the events in dispute in Kilwa, Anvil Mining had no establishment in Quebec and did not carry on any activities in Quebec. ${ }^{118}$ Anvil Mining did not open its Quebec establishment, an office in Montreal, until June 2005, more than six months after the events in Kilwa. ${ }^{119}$ The Court rejected Anvil Mining's argument on this point noting that there was no requirement under the CCQ that the referenced establishment must exist when the facts giving rise to liability occur. Rather, the Court held that it was sufficient that the establishment existed in Quebec when the action was brought. ${ }^{120}$

Anvil Mining's second argument to dispute jurisdiction was that the dispute at issue in the claim did not relate to Anvil Mining's activities in Quebec. The Montreal office had two employees, an executive responsible for maintaining relationships with investors and shareholders, and a part-time administrative assistant. The Court rejected this argument as well. The Court held that the evidence showed that the only activity of Anvil Mining was the operation of mines in Africa and that the activities of the Montreal office were inextricably linked to those carried out in the DRC. Further, the Court found that the Montreal office was directly involved in managing the crisis created by the events in question. ${ }^{121}$ The Court concluded therefore that the role of the Montreal-based Anvil Mining employees was necessarily linked to the operation of the mine in DRC since it was the only activity of the corporation. ${ }^{122}$

Having failed on the first ground of its motion to establish that the Court lacked jurisdiction over the claim, Anvil Mining argued the Court ought to decline jurisdiction on the basis that Quebec was clearly an inappropriate forum while another forum (either Australia, the location of Anvil Mining's head office, or DRC) was clearly the more appropriate forum to resolve the dispute between the parties involved. ${ }^{123}$

The plaintiff argued previous attempts to seek redress in proceedings in DRC and Australia were thwarted and those jurisdictions were therefore not clearly more appropriate. The Supreme Military Court of the DRC had conducted a trial of members of the military and three Anvil Mining executives in 2007 in respect of the Kilwa incident. Several civilian victims joined the military proceeding and advanced civil claims. These claims were denied by the Court. Two members of the military were convicted of murder, not war crimes, and all others, including the Anvil Mining executives, were acquitted. ${ }^{124}$ The plaintiff submitted that the Office of the United Nations High Commissioner for Human Rights had expressed concerns with the lack of impartiality and independence within the Congolese military justice system in this proceeding. ${ }^{125}$ Anvil Mining provided evidence to the Court from an expert in Congolese law to dispute the allegation that the proceedings lacked fairness. ${ }^{126}$ As well, the expert noted that the civilian participants in the military proceeding could have appealed the

Anvil (Qc CS), supra note 13 at para 12.

Ibid.

Ibid at para 16, citing Rees c Convergia, 2005 QCCA 353, [2005] JQ No 3248 (QL) at paras 48-49.

Anvil (Qc CS), ibid at para 11.

Ibid at para 29.

Ibid at paras 30-32.

Anvil (Qc CA), supra note 13 at paras 27-29.

Ibid at para 33, citing United Nations Human Rights Office of the High Commissioner, Democratic Republic of the Congo, 1993-2003: Report of the Mapping Exercise (August 2010) at para 869. Anvil (Qc CA), ibid at para 32. 
dismissal of their claims to the Congolese Supreme Court of Justice but that they did not do so. ${ }^{127}$

In 2007, a class action was brought in Australia on behalf of a number of victims of the Kilwa events. ${ }^{128}$ According to the allegations in the plaintiff's motion, "the Congolese government impeded the movements of the victims" preventing them from providing instructions to Australian counsel. ${ }^{129}$ The Australian firm that had taken the case ultimately withdrew, and the plaintiff alleged that the victims were unable to find other legal counsel willing to carry on the action in Australia. ${ }^{130}$

The Court concluded it was impossible to determine that the DRC authorities or those of Australia would be much more appropriate to resolve the dispute. The Court further noted that at this stage of the proceedings, everything indicated that if the Court dismissed the action on the basis of forum, there would be no other possibility for victims to be heard by a civil justice system. ${ }^{131}$ The Court dismissed Anvil Mining's motion challenging jurisdiction.

The plaintiff had also raised an additional basis for jurisdiction - the jurisdiction of necessity. This doctrine holds that in certain cases, despite the absence of a real and substantial connection, where there is no other forum in which a plaintiff can reasonably see relief, there is a residual discretion of the courts to assume jurisdiction. ${ }^{132}$ This concept is codified in article 3136 of the CCQ which provides that if a Quebec court does not have jurisdiction, it may accept jurisdiction only in exceptional circumstances. ${ }^{133}$

The concept of jurisdiction of necessity has received little judicial consideration in Canada. ${ }^{134}$ In the 2010 case of Charron Estate v. Village Resorts Ltd., the Ontario Court of Appeal considered the circumstances in which a court may invoke jurisdiction of necessity:

\footnotetext{
The forum of necessity doctrine recognizes that there will be exceptional cases where, despite the absence of a real and substantial connection, the need to ensure access to justice will justify the assumption of jurisdiction. The forum of necessity doctrine does not redefine real and substantial connection to embrace "forum of last resort" cases; it operates as an exception to the real and substantial connection test. Where there is no other forum in which the plaintiff can reasonably seek relief, there is a residual discretion to assume jurisdiction. In my view, the overriding concern for access to justice that motivates the assumption of jurisdiction despite inadequate connection with the forum should be accommodated by explicit recognition of the forum of necessity exception rather than by distorting the real and substantial connection test. ${ }^{135}$
}

The Van Breda decision was appealed to the Supreme Court but that court declined to consider the issue of jurisdiction of necessity beyond a passing reference that where a court

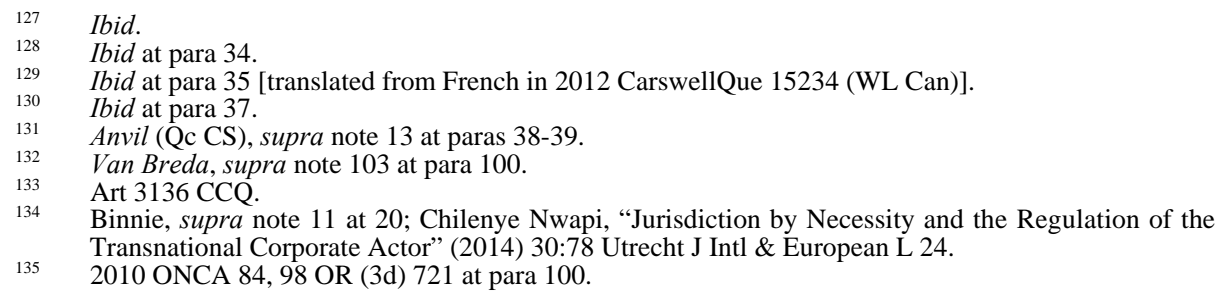


determines that it does not possess jurisdiction over a dispute "it must dismiss or stay the action, subject to the possible application of the forum of necessity doctrine, which [the Court] need not address in these reasons." 136

Given that the Superior Court of Quebec dismissed Anvil Mining's motion, it did not rule whether these facts constituted exceptional circumstances sufficient to justify invoking the doctrine of jurisdiction of necessity. ${ }^{137}$

\section{COURT OF APPEAL}

Anvil Mining successfully appealed the denial of its motion to the Quebec Court of Appeal. The Court of Appeal considered the timing of the opening of Anvil Mining's Quebec establishment and held that the "complete lack of an establishment and activities [of a defendant in a jurisdiction] when the facts giving rise to liability occur is certainly a significant element to determine whether the dispute relates to its activities in Quebec."138 Applying this logic, the Court of Appeal was unable to find a connection between the faults allegedly committed by Anvil Mining at the time of the Kilwa events in October 2004 and any activities allegedly undertaken in Quebec in June 2005, and thus, was unable to find a real and substantial connection with Quebec authorities. ${ }^{139}$ The Court granted Anvil Mining's appeal and ruled that Quebec did not have jurisdiction over the claim. In light of this finding, the Court did not consider the issue of appropriate forum but did address the availability of the doctrine of the jurisdiction of necessity.

Article 3136 of the CCQ codifies the concept of jurisdiction of necessity in Quebec civil procedure:

Even though a Québec authority has no jurisdiction to hear a dispute, it may nevertheless hear it provided the dispute has a sufficient connection with Québec, if proceedings cannot possibly be instituted outside Québec or where the institution of such proceedings outside Québec cannot reasonably be required. ${ }^{140}$

The Court cited examples of the exceptional circumstances where this provision may be engaged including the breakdown of diplomatic or commercial relations with a foreign state, the need to protect a political refugee, or the existence of a serious physical threat if the dispute were to be undertaken before the foreign court. ${ }^{141}$ The Court noted that a party seeking to rely on article 3136 bears the burden of proof to establish the existence of one of these exceptional circumstances. ${ }^{142}$

The exceptional circumstance considered by the Court in Anvil was the ability of the victims to obtain justice in the DRC or to apply successfully to tribunals in Australia. ${ }^{143}$ The

\footnotetext{
$136 \quad$ Van Breda, supra note 103 at para 100.

$137 \quad$ Anvil (Qc CA), supra note 13 at para 49.

$138 \quad$ Ibid at para 79 [translated from French in 2012 Carswell Que 15234 (WL Can)] [emphasis in original].

$139 \quad$ Ibid at para 93.

140 Art 3136 CCQ.

141 Anvil (Qc CA), supra note 13 at para 98, citing Lamborghini (Canada) Inc c Automobili Lamborghini SPA (1996), [1997] RJQ 58 at paras 44-47.

$142 \quad$ Anvil (Qc CA), ibid at para 99.

$143 \quad$ Ibid at para 96.
} 
Court held that the plaintiff had failed to present evidence to specifically counter Anvil Mining's expert witness who had expressed the opinion that the victims participating in the military court could have brought their case to the Congolese Supreme Court of Justice. ${ }^{144}$ Further, the Court noted that the information filed by the plaintiff was restricted to commentary on the military court proceeding specifically and did not address how proceedings would unfold before the Supreme Court of Justice should those victims have appealed. ${ }^{145}$ Regarding the Australian proceeding, the Court noted that Australia was not a country where it may be believed that its citizens were treated unfairly or unequally before the courts. ${ }^{146}$ The Court found that the only reason apparently barring the victims from going before the Australian courts was the difficulty in convincing counsel to bring proceedings. ${ }^{147}$ The Court noted that it did not have evidence before it of what measures had been taken to that end. ${ }^{148}$

The Court concluded that the plaintiff had not demonstrated that it would be impossible to gain access to a foreign tribunal and had not established that the case had a sufficient connection to Quebec to meet the requirements of article 3136 of the CCQ. ${ }^{149}$

Commentators have noted that the Court of Appeal failed to consider in its reasons for judgment the third basis for taking jurisdiction under article 3136. ${ }^{150}$ Applying this criterion, even if it were conceded that it was not absolutely impossible for the victims to take action in Australia, it may have been possible for the Court to conclude that the circumstances could justify that it would not be reasonable to require that applicants institute proceedings there. ${ }^{151}$ Unfortunately this issue remains unresolved as the Supreme Court of Canada refused to hear the appeal of the decision of the Quebec Court of Appeal. ${ }^{152}$

\section{CONCLUSION}

While the Court of Appeal certainly took a more narrow view of jurisdiction than the Superior Court, the Anvil case does not close the door to future claims in Quebec by foreign plaintiffs as suggested by some commentators. ${ }^{153}$ The Anvil Court of Appeal decision instead provides helpful guidance for future claims. When making arguments relating to forum or jurisdiction of convenience, plaintiffs will have to provide focused and comprehensive evidence as to the specific barriers faced by the plaintiffs in commencing proceedings in other jurisdictions. As well, any plaintiff seeking to rely on article 3136 will have to advance an argument which carefully addresses all criteria for a finding of jurisdiction of necessity.

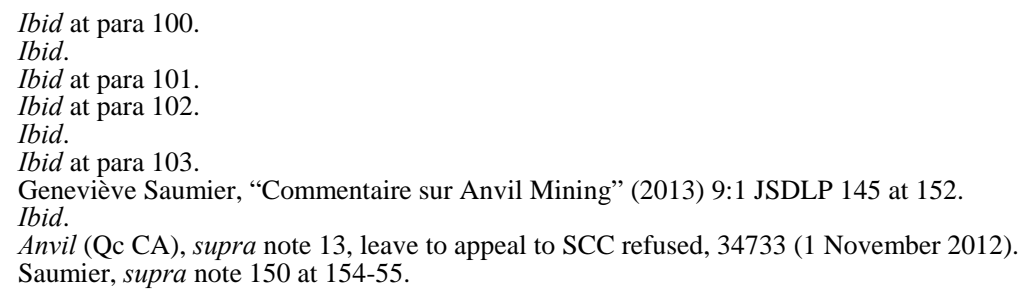




\section{YAiguaje V. CHEVRON CORP. - RECOGNITION OF FOREIGN JUDGMENTS}

A defendant that succeeds in having a claim stayed for reasons of jurisdiction may find itself back in court facing a proceeding for the recognition of a foreign judgment. If a Canadian court determines that it does not have jurisdiction or that some other jurisdiction is a more convenient forum, that plaintiff may still return to a Canadian court with a judgment obtained in their home country and bring an action for recognition of that judgment in Canada:

[T]o the extent that [multinational corporations] take the benefit of doing business in foreign jurisdictions, they also need to be aware that their activities may be scrutinized by the courts of those jurisdictions. This is particularly so if efforts to litigate in domestic courts have failed as a result of negative preliminary jurisdictional determinations. If a court rejects a claim on forum non conveniens grounds, based partly on the notion that a foreign state has "the proven capacity to mete out fair and equal justice," it should take a close look at a subsequent argument that a judgment from that foreign jurisdiction should not be enforced locally. $^{154}$

In Beals v. Saldanha, ${ }^{155}$ the Supreme Court considered circumstances where a foreign judgment would be recognized in Canadian courts, with Justice Major for the majority noting that "[i]nternational comity and the prevalence of international cross-border transactions and movement call for a modernization of private international law." "156 The threshold issue for recognition of a foreign judgment is that there be a "real and substantial connection" between the cause of action and the foreign court. ${ }^{157}$ There are a number of defences available to a domestic defendant in contesting the recognition of a foreign judgment, including: (1) raising new and material facts, not available to the foreign court, which evidence that the foreign judgment was obtained by fraud; ${ }^{158}$ (2) establishing that the foreign proceedings were contrary to Canadian notions of fundamental justice and the defendant was not granted a fair process; ${ }^{159}$ and (3) showing that enforcement of the foreign judgment is contrary to the Canadian concept of justice as a matter of public policy. ${ }^{160}$

In Yaiguaje, the Ontario Superior Court considered an action brought by Ecuadorian citizens for the recognition of a judgment obtained by the plaintiffs in the Ecuadorian courts against Chevron Corporation. Chevron Corporation is a US corporation incorporated in Delaware with its head office in San Ramon, California. ${ }^{161}$ In the Ontario Superior Court proceeding, the plaintiffs named Chevron Corporation as a defendant, as well as a Canadian subsidiary, Chevron Canada Limited (Chevron Canada) that was neither a party to the

Farrow, supra note 69 at 708-709 [footnotes omitted]. 2003 SCC 72, [2003] 3 SCR 416 [Beals].

Ibid at para 28.

Ibid at para 32

Ibid at para 50.

Ibid at para 59.

Ibid at para 71. The Court provides a warning about utilizing this defence at para 75 :

The use of the defence of public policy to challenge the enforcement of a foreign judgment involves impeachment of that judgment by condemning the foreign law on which the judgment is based. It is not a remedy to be used lightly. The expansion of this defence to include perceived injustices that do not offend our sense of morality is unwarranted. The defence of public policy should continue to have a narrow application. 
Ecuadorian proceedings nor named in the Ecuadorian judgment. ${ }^{162}$ Chevron Canada is an operating company and seventh-level indirect subsidiary of Chevron with its head office in Calgary, Alberta, and sales offices in Mississauga, Ontario. ${ }^{163}$ The defendants brought a motion to stay the plaintiff's claim for recognition of the Ecuadorian judgment on the basis that there was no real and substantial connection between the defendants and the original Ecuadorian proceeding.

The underlying Ecuadorian proceeding concerned a claim brought by residents of the Lago Agrio region of the Ecuadorian Amazon against the US corporation, Chevron Corporation. ${ }^{164}$ The plaintiffs alleged that oil extraction activities of Chevron Corporation's predecessor, Texaco, from about 1970 to 1990 had caused extensive pollution in the Lago Agrio region. Following trial, the Ecuadorian courts granted a multi-billion dollar judgment in favour of the plaintiffs. ${ }^{165}$ It was this judgment that the plaintiffs were attempting to have recognized in the Ontario courts. ${ }^{166}$

The defendants sought a stay of the Ontario proceeding on the basis that the plaintiffs had not met the threshold issue of establishing the jurisdiction of the Ontario courts over the recognition of the foreign judgment. Chevron Corporation argued that it did not reside or conduct business in Ontario, had no assets in Ontario and did not own shares in Chevron Canada. Chevron Canada argued that the Ecuadorian judgment was against Chevron Corporation and that it was a separate legal identity which was never a party to the Ecuadorian proceedings and was not a judgment debtor of the plaintiffs. ${ }^{167}$

The plaintiffs argued that the only precondition to establishing Ontario jurisdiction in the context of the recognition of a foreign judgment is that the foreign court which rendered the judgment had a real and substantial connection to the litigants and subject matter. In particular, the plaintiffs argued that the recognition of a foreign judgment does not depend on the location of a judgment debtor's assets. ${ }^{168}$

The Court accepted the plaintiffs' arguments and refused to grant the stay on the basis of lack of jurisdiction. ${ }^{169}$ However, the Court went on to grant a stay of the Ontario proceeding on two other grounds, neither of which was requested by the parties.

Yaiguaje (Sup Ct), supra note 74 at paras 2-3.

Ibid at paras 17-18.

Yaiguaje (CA), supra note 74 at para 8. While the underlying action in Yaiguaje related to claims arising from environmental damage, the issues raised in the Ontario proceedings are instructive for any future claims to recognize a judgment obtained in a foreign court in respect of human rights violations.

The first judgment granted damages, including punitive damages, in the amount of approximately \$18 billion. The punitive damages amount was overturned on appeal and the judgment was reduced to $\$ 9.51$ billion: ibid at paras 9-10.

In 2011, Chevron Corporation obtained a global anti-enforcement injunction against the plaintiffs in respect of the Ecuadorian judgment in the district court of New York. Chevron Corporation obtained the injunction prior to any enforcement steps being taken by the plaintiffs. The Second Circuit overturned the injunction on appeal on the grounds that legislation relating to the recognition of foreign judgments relied upon by Chevron Corporation can only be invoked defensively in response to an attempt to enforce and does not create a cause of action. The Court held that the plaintiffs may seek to enforce the Ecuadorian judgment in any country in the world where Chevron Corporation has assets. See Chevron Corporation v Naranjo, 667 F (3d) 232 (2d Cir 2012).

Yaiguaje (Sup Ct), supra note 74 at paras 14-15.

Ibid at para 26.

Ibid at para 77. 
The defendants invoked section 106 of the Courts of Justice Act, which provides that “[a] court, on its own initiative or on motion by any person, whether or not a party, may stay any proceeding in the court on such terms as are considered just," ${ }^{170}$ as support for seeking a stay of the claim on the basis that the Court lacked jurisdiction.

In rendering its judgment, the Court took "its own initiative” pursuant to section 106 and stayed the action on two grounds separate from the issue of jurisdiction: (1) recovery through the enforcement of the Ecuadorian judgment in Ontario was unlikely to be successful as Chevron Corporation did not presently possess any assets in Ontario, and its evidence was that it had no intention of ever owning any assets in Ontario; and (2) the plaintiffs had "no hope of success in their assertion that the corporate veil of Chevron Canada should be pierced and ignored so that its assets become exigible to satisfy [the Ecuadorian judgment] against its ultimate parent." 171 The Court went on to note that if the claim for recognition of the foreign judgment were allowed to proceed, there was evidence that the dispute would be "bitter, protracted and expensive," which would unnecessarily consume judicial resources. ${ }^{172}$ In support of this proposition, the Court took note of Chevron Corporation being on the record saying, “[w]e will fight until hell freezes over and then fight it out on the ice."173

\section{COURT OF APPEAL}

The parties appealed to the Ontario Court of Appeal, the plaintiffs appealing the stay, and the defendants cross-appealing on the Court's recognition of Ontario having jurisdiction to hear the action. The Court of Appeal upheld the motion judge's finding regarding jurisdiction, confirming that the relevant inquiry was the real and substantial connection of the court of the original jurisdiction to the parties or subject matter of the claim and not that of the connection between Ontario courts and the judgment debtors.

The Court, however, overturned the stay of the plaintiffs' action noting that it was not a remedy requested by the parties and that circumstances where a court may take its own initiative to grant such a stay are rare. ${ }^{174}$ The Court also noted that the stay was granted without giving the plaintiffs an opportunity to make argument or compile a record on the likelihood of recovery through enforcement or the corporate veil issues. The Court noted that the factors cited as the basis for the grant of the extraordinary stay may ultimately derail the plaintiffs' efforts for recognition and enforcement of the Ecuadorian judgment. ${ }^{175}$ The Court felt, however, that derailment at a preliminary stage was premature, stating that " $\mathrm{t}] \mathrm{his}$ case cries out for assistance, not unsolicited and premature barriers." ${ }^{\text {,176 }}$

The Court concluded that Chevron would have its wish to "fight it out" on its merits: "After all these years, the Ecuadorian plaintiffs deserve to have the recognition and

RSO 1990, c C.43, s 106.

Yaiguaje (Sup Ct), supra note 74 at paras 109-10.

Ibid at para 111.

Ibid.

Yaiguaje (CA), supra note 74 at para 54.

Ibid at para 63.

Ibid at para 72. 
enforcement of the Ecuadorian judgment heard on the merits in an appropriate jurisdiction. At this juncture, Ontario is that jurisdiction."177

\section{CONCLUSION}

The decision of whether to recognize a foreign judgment "potentially means the difference between a remedy granted and a remedy denied" for a plaintiff. ${ }^{178}$ In the Chevron case, the Court of Appeal was adamant that the plaintiffs have an opportunity to make their case for the recognition of the Ecuadorian judgment rather than being shut out at a preliminary stage. The Court noted that in allowing the claim to proceed, the defendants will still have the opportunity to raise all available defences to the recognition of a foreign judgment as set out in Beals.

On 16 January 2014, the Chevron defendants obtained a stay of the Ontario Court of Appeal's order pending the outcome of the notice for leave to appeal to the Supreme Court. ${ }^{179}$ On 4 March 2014, the US District Court of the Southern District of New York issued a decision nearly 500 pages long in which the Court found that the original Ecuadorian judgment that is the subject of the Canadian proceedings had been obtained by corrupt means and was the product of fraud and racketeering activity. ${ }^{180}$ As a result, the Court ruled that the plaintiffs are barred from enforcing the Ecuadorian judgment in the US.

On 3 April 2014, the Chevron defendants were granted leave to appeal by the Supreme Court of Canada. ${ }^{181}$ It is likely that the recent US decision will have an impact on the Canadian proceeding, if not at the Supreme Court on the preliminary motion relating to jurisdiction, then certainly at any substantive hearing of the plaintiffs' claim for recognition of the Ecuadorian judgment.

\section{DEVELOPMENTS AND FUTURE CHANGES IN CANADIAN LAW}

\section{A. Bill C-323 An ACt to AMEND the Federal Courts ACT (INTERNATIONAL PROMOTION AND PROTECTION OF HUMAN RIGHTS)}

The issues raised by foreign plaintiffs litigating extraterritorial human rights claims has been noted by members of Parliament. On 5 October 2011, Peter Julian, Member of Parliament for Burnaby-New Westminster, introduced a private member's bill to create a Canadian version of the ATS. Bill C-323 An Act to amend the Federal Courts Act (international promotion and protection of human rights) is intended to amend the Federal Courts Act "to expressly permit persons who are not Canadian citizens to initiate tort claims based on violations of international law or treaties to which Canada is a party if the acts alleged occur outside Canada.”182 
The bill sets out the manner in which the Federal Court and Federal Court of Appeal may exercise their jurisdiction to hear and decide such claims. The proposed amendment prescribes an expanded jurisdiction for the Federal Courts in hearing claims by foreign plaintiffs relating to crimes against humanity, systemic discrimination, violations of internationally recognized human rights, human trafficking, military conscription of youth, sexual violence, wanton destruction of the environment, trans-boundary pollution, failure to warn of impending environmental emergency, and violations of fundamental conventions of the International Labour Organization. ${ }^{183}$

Bill C-323 expressly allows for extraterritorial application, avoiding the problem raised by the US Supreme Court in Kiobel with respect to the ATS. The bill reflects a desire, at least in some political quarters, to create a legislative solution to the issues raised by Justice Binnie. However, until such legislation is passed, the courts will remain the gatekeepers of civil procedure and the access of justice. ${ }^{184}$

\section{CONCLUSION}

Extraterritorial human rights litigation in Canada currently proceeds in a piecemeal fashion, province by province, case by case. As Justice Binnie noted, "the law has a lot of catch-up work to do.”185 Absent a legislative solution, the courts will be left to develop a Canadian approach to this kind of litigation. This will likely occur slowly and at a great cost to the parties involved in these proceedings. Such an approach may be less favourable than a deliberately designed procedure created in consultation with stakeholders, in particular the Canadian international extractive sector. Collaboration between industry, government, and public interest groups has already occurred in the CSR sphere. Extraterritorial human rights litigation can be seen, in some part, as an extension of this process. Canadian corporations, particularly those in the international extractive sector, will continue to face this type of litigation. Change is coming, whether through legislation or the boldness of the Canadian judiciary. It would appear that presently, the courts are currently outpacing Parliament. 